This item was submitted to Loughborough's Research Repository by the author.

Items in Figshare are protected by copyright, with all rights reserved, unless otherwise indicated.

\title{
The Lords Howard's Men at the Rose and on Tour in 1599
}

PLEASE CITE THE PUBLISHED VERSION

PUBLISHER

C) Oxford University Press

LICENCE

CC BY-NC-ND 4.0

REPOSITORY RECORD

Egan, Gabriel. 2019. "The Lords Howard's Men at the Rose and on Tour in 1599”. figshare. https://hdl.handle.net/2134/264. 


\section{Loughborough}

This article has been submitted to Loughborough University's Institutional

Repository by the author.

Egan, Gabriel. 1999. "The Lords Howard's Men at the Rose and on Tour in 1599." Notes and Queries. vol. 244. pp. 234-36. ISSN 0029-3970

\section{THE LORDS HOWARD'S MEN AT THE ROSE AND ON TOUR IN 1599}

Thomas Platter's account of his trip to a South London playhouse on 21 September 1599 to see a 'tragedy of the first Emperor Julius Caesar' might be an eyewitness account of Shakespeare's Julius Caesar. It might, however, be something rather less interesting: an account of an unknown play at the Rose (Schanzer 1956, 466-67). In determining which playhouse, and hence which play, Platter visited, it would be useful to know what the Rose players were doing in the summer and autumn of 1599.

Gary Taylor argued that Platter probably went to see Shakespeare's company at the Globe, rather than the Lord Admiral's men at the Rose, because `. . . Henslowe's records for that year give no indication of any such play in their [the Admiral's men's] repertoire. . .' (Wells et al. 1987, 121). In fact Henslowe recorded no income for the Admiral's men in the summer of 1599 and in any case since October 1597 Henslowe had ceased noting play titles alongside income records. Payments to dramatists tell us of new works entering the repertoire but 'seser and pompey', which played in 1594-5, might have been revived in 1599 (Foakes \& Rickert 1961, 25-27, 30).

The absence of records of income at the Rose between 3 June and 6 October is puzzling. The gap in Henslowe's receipts cannot be due to a sheet being lost to us since, although the 6 October entry begins a new list for the autumn season on folio $62 \mathrm{v}$, a list on folio $48 \mathrm{v}$ places a copy of the entries for 6 October and 13 October on adjacent lines directly after the 3 June entry (Foakes \& Rickert 1961, 95, 120-21). One explanation considered by Carol Chillington Rutter is that the Rose was closed for the summer (Rutter 1984, 168), although Henslowe continued to pay for books and costume material (Foakes \& Rickert 1961, 121-24). If the Rose was closed until 6 October, then on 21 September Platter must have gone to the Globe, in which case he saw Shakespeare's play. But Henslowe's list of receipts for the autumn season is headed 'Heare I begane to Receue the gallereys agayne / $\mathrm{w}^{\mathrm{ch}}$ theye Receued begynynge at myhellmas wecke / beinge the 6 of octob' which might suggest that the Rose was open during the summer but Henslowe was not receiving 
any income. Rutter considered how such a state of affairs might have come about:

'I begane to Receue the gallereys agayne wch theye Receued begynynge at myhellmas wecke' might be interpreted to mean that the players, having turned over their 'wholle gallereyes' to Henslowe for the twelve months preceding, collected the galleries themselves during the summer, then, in the autumn, resumed the old arrangement of paying off their loans by handing Henslowe their gallery money. (Rutter 1984, 168)

Either of Rutter's explanations--that the Rose was closed for the summer, or that the company kept all the gallery income and so Henslowe recorded none-fits the facts and there is at present nothing to choose between them. However, in a study of the playing companies, Andrew Gurr presented evidence of provincial payments which appear to place the Admiral's men on tour in the autumn of 1599 , and hence not at the Rose:

Bristol Sept.-Dec. 1599 'to my Lorde Hawardes players', 30s. / Leicester Oct. 1599 'to the Lorde Haywardes playars more then was gaythered', 18s. 8‥ I Coventry 28 Dec. 1599 'the Lord hawardes players', 10s (Gurr 1996, 255)

The Coventry payment is the most interesting because it seems to put the Rose players, the men of Lord Howard the Lord Admiral, 100 miles from London just two days before Henslowe received 10 pounds and 8 shillings for the Rose galleries on 30 December 1599 (Foakes \& Rickert 1961, 120). If the Lord Admiral's men were on tour throughout the autumn of 1599 then Henslowe's record of income beginning on 6 October indicates that another company played at the Rose, or else the 'gallereys' providing this income were not those of the Rose. If the Rose was closed while its resident company was on tour in the autumn of 1599 then Platter's 'tragedy of the first Emperor Julius Caesar' must have been Shakespeare's play at the only playhouse left open in Southwark, the Globe. The cost of removing the uncertainty about Platter's account would be high: either another company about whom we know nothing was playing at the Rose in the autumn of 1599, or else Henslowe's records are not those of the Rose and hence they are even more baffling than we thought.

Fortunately, the sanity of those interested in this subject has been preserved by the decision of the Records of Early English Drama project to re-assign the troublesome touring records to the patronage of William Howard, son of the Lord Admiral Charles Howard (Tiner 1996, 15). The re-assignment was made when it was noticed that Charles Howard was created '10th earl of Nottingham [on] 22 October 1597' (Tiner 1996, 24) and that thereafter his son William was styled 'Lord Howard'. Gurr's provincial records can therefore be ignored because they refer not to the Rose company, the Lord Admiral's men, but to another troupe of players under the patronage of the Lord Admiral's son. This being the case, and with no other evidence available to tip the balance of probabilities, we should not assume that Platter went to the Globe to see Shakespeare's play. 


\section{Notes}

Foakes, R. A. and R. T. Rickert, eds. 1961. Henslowe's Diary, Edited with Supplementary Material, Introduction and Notes. Cambridge. Cambridge University Press.

Gurr, Andrew. 1996. The Shakespearian Playing Companies. Oxford. Clarendon Press.

Rutter, Carol Chillington, ed. 1984. Documents of the Rose Playhouse. The Revels Plays Companion Library. Manchester. Manchester University Press.

Schanzer, Ernest. 1956. "Thomas Platter's Observations on the Elizabethan Stage." Notes and Queries. 201. 465-67.

Tiner, Elza C. 1996. "Patrons and Travelling Companies in Coventry." Records of Early English Drama Newsletter. 21.1. 1-37.

Wells, Stanley, Gary Taylor, John Jowett and William Montgomery. 1987. William Shakespeare: A Textual Companion. Oxford. Oxford University Press. 